\title{
Overweight, Alcohol, and Tobacco Consumption Are Associated with Hypertension among Police and Military Personnel: A Meta-Analysis
}

\author{
Firman Pardosi'), Setyo Sri Rahardjo²), Yulia Lanti Retno Dewi²) \\ 1)Masters Program in Public Health, Universitas Sebelas Maret \\ 2)Faculty of Medicine, Universitas Sebelas Maret
}

\section{ABSTRACT}

Background: Increased blood pressure for a long time can increase the risk of kidney failure, coronary heart disease, brain damage, and other diseases. In 2019, it is estimated that hypertension is experienced by 1.13 billion people in the world with most (two thirds) living in low and middle income countries. Other study also shows that the police and military are at risk of developing hypertension due to a number of factors such as low knowledge about healthy and nutritious food, co-workers who are smokers, and consuming alcohol. This study aimed to analyze the risk factors for hypertension in the police and military in the world using meta analysis.

Subjects and Method: This was a meta-analysis and systematic review. The articles used were obtained from Google Scholar, Springer Link, ProQuest, and Science Direct databases. Selected articles published from 2000 to 2020. Keywords to search for articles are as follows: hypertension police personnel and military, or hypertension police personnel and military. The articles studied are 3 full text articles with cross sectional stu- dy designs and 1 full text articles with case control study design. Articles are collected using PRISMA diagrams, and analyzed using the Review Manager application 5.3.

Results: Overweight $(\mathrm{aOR}=1.42 ; 95 \% \mathrm{CI}=1.01$ to 2.00; $\mathrm{p}=0.04)$, alcohol consumption $(\mathrm{aOR}=1$. $55 ; 95 \% \mathrm{CI}=1.12$ to $2.12 ; \mathrm{p}=0.007$ ), cigarette consumption $(\mathrm{aOR}=1.45 ; 95 \% \mathrm{CI}=1.06$ to 1.97 ; $\mathrm{p}=0.020$ ) is a risk factor for hypertension in the police and military.

Conclusion: Overweight, alcohol consumption, and cigarette consumption, are risk factors for hypertension in police and military personnel.

Keywords: overweight, alcohol, smoking, hypertension, meta analysis

\section{Correspondence:}

Firman Pardosi. Masters Program in Public Health, Universitas Sebelas Maret, Jl. Ir. Sutami 36A, Surakarta 57126, Central Java. Email: pardosi.fp@gmail.com.Mobile: +6285261423865.

\section{Cite this as:}

Pardosi F, Rahardjo SS, Dewi YLR (2020). Overweight, Alcohol, and Tobacco Consumption Are Associated with Hypertension among Police and Military Personnel: A Meta-Analysis. J Epidemiol Public Health. 05(01): 88-96. https://doi.org/10.26911/jepublichealth.2020.05.01.09.

(c) (i) (-) Journal of Epidemiology and Public Healthis licensed under a Creative Commons EY No Sa Attribution-NonCommercial-ShareAlike 4.0 International License.

\section{BACKGROUND}

Hypertension or high blood pressure is an increase in systolic blood pressure of more than $140 \mathrm{mmHg}$ and diastolic blood pressure of more than $90 \mathrm{mmHg}$ at two measurements with an interval of five minutes in a state of sufficient rest/calm. Increased blood pressure that lasts for a long time (persistent) can cause kidney failure, coronary heart disease, and disorders of the brain if not detected ear- ly and receive adequate treatment (Ministry of Health, 2014).

In 2019, the prevalence of hypertension is estimated at 1.13 billion people worldwide with most or two-thirds living in low and middle income countries. In 2015, an estimated 1 in 4 men and 1 in 5 women suffered from hypertension (WHO, 2019). 
Factors that cause high blood pressure consist of factors that cannot be changed and that can be changed. Factor which cannot be changed include age, gender, and genetic factors. Factors that can be changed include physical activity, fat consumption, nutritional status, sodium/salt consumption, smoking habits, alcoholic beverage consumption habits, and stress (Saputra and Anam, 2016).

Research on the police in Sudan found a significant relationship between BMI> 25 $\mathrm{kg} / \mathrm{m}^{2}$ and hypertension and $\mathrm{OR}=2.33$ (Aisha et al., 2008). Research on the police in West Bengal, India shows that the risk of hypertension is influenced by cigarette consumption with $\mathrm{OR}=1.2$ (Mallik et al., 2014). Research on the police in Ethiopia shows that the risk of hypertension is influenced by alcohol consumption with $\mathrm{OR}=1.2$ (Tesfaye, 2017).

A study in the military in Saudi Arabia shows that the risk of hypertension is influenced by BMI $>25 \mathrm{kgBW} / \mathrm{m}^{2}$ with $\mathrm{OR}=$ 3.14 and smoking habits with $\mathrm{OR}=1.51$ (AlAsmary et al., 2008). In Indonesian soldiers, hypertension is also influenced by cigarette consumption with $\mathrm{OR}=2.61$ (Oktavia and Martini, 2016). Military study in Kenya shows the risk of hypertension was influenced by alcohol with $\mathrm{OR}=1.56$ (Mundan et al., 2013).

The purpose of this study was to analyze the risk factors for hypertension in the police and military in the world using meta analysis.

\section{SUBJECTS AND METHOD}

\section{Study Design}

This was a meta-analysis and systematic review. The articles used in this study were obtained from Google Scholar, Springer Link, ProQuest, and Science Direct databases, from 2000 to 2020. The keywords used in searching for articles were hypertension po- lice personnel and military, or hypertension police personnel and military.

\section{Population dan Sample}

The articles included in this study are article texts with cross sectional study and case control study. The article chosen discusses the effects of being overweight, alcohol consumption, and cigarette smoke. The article used is an article published in English. The study subjects were the police and military personnel. The results of the study were reported using adjusted Odds Ratio (aOR).

\section{Inclusion and Exclusion Criteria}

The exclusion criteria in this study were articles with RCT study designs, cohort study, quasy experiments, and protocol studies. Article not published in English. The statistical results reported are not aOR.

4. Operational Definition of Variables Overweight was a disorder or disease characterized by excessive accumulation of fat or body tissue.

Alcohol consumption was the pattern of an individual in choosing and consuming alcohol in the form of drinks such as beer, whiskey, vodka, wine, and others.

Cigarette smoke was a person's activity which includes the act of burning cigarettes then smoking cigarette smoke and exhaling it out as measured by the number of cigarettes smoked per day.

Hypertension was an abnormal increase in blood pressure in arteries with a measure of systolic blood pressure more than $140 \mathrm{mmHg}$, and/ or diastolic blood pressure $\geq 90 \mathrm{mmHg}$ at two measurements with an interval of 5 minutes in a state of adequate rest.

\section{Data Analysis}

Data processing is performed using Review Manager (RevMan 5.3) by calculating the value of effect sizes and heterogeneity to determine the combined study model and form the final result of a forest plot meta-analysis. 


\section{RESULTS}

The process of articles selection is shown in Figure 1. Figure 2 shows the area where the selected articles were published. They were from 2 continents; Asia and Africa.

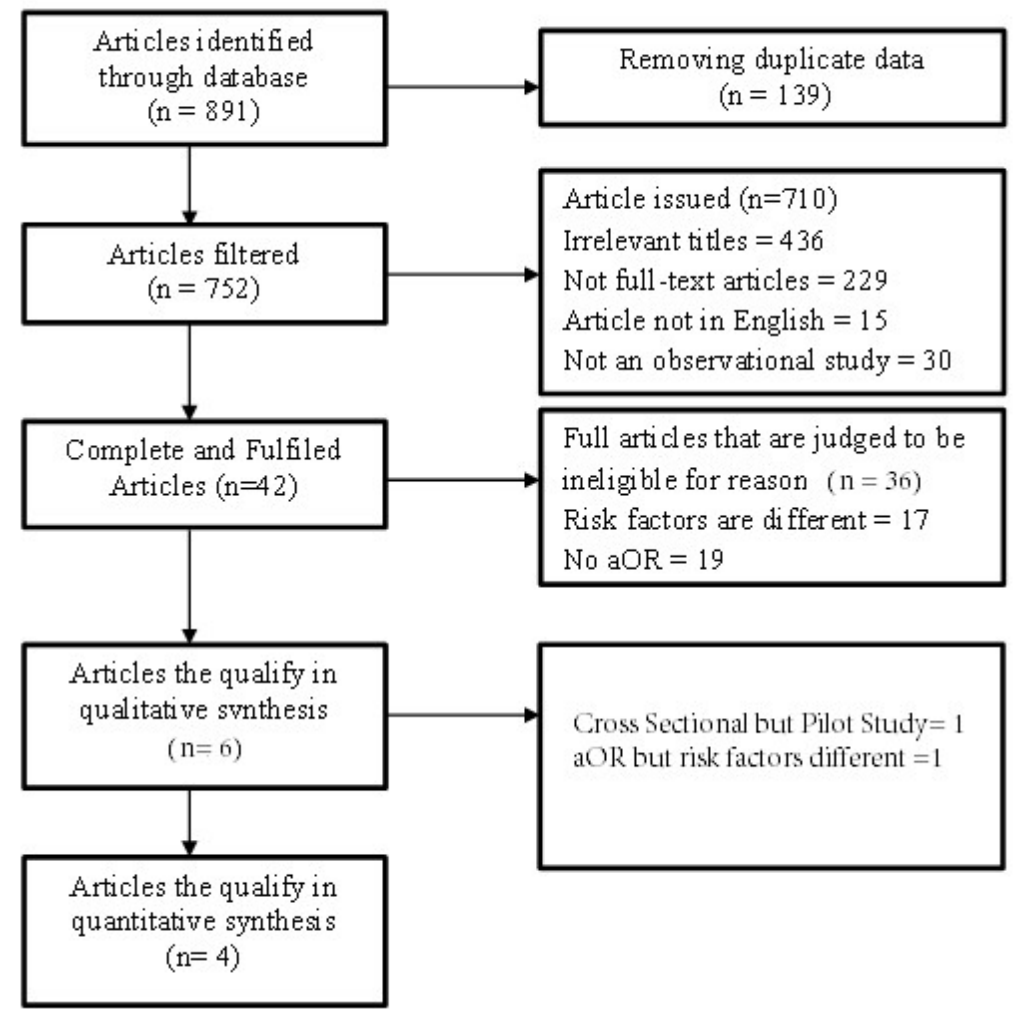

Figure 1. Flowchart of the review process

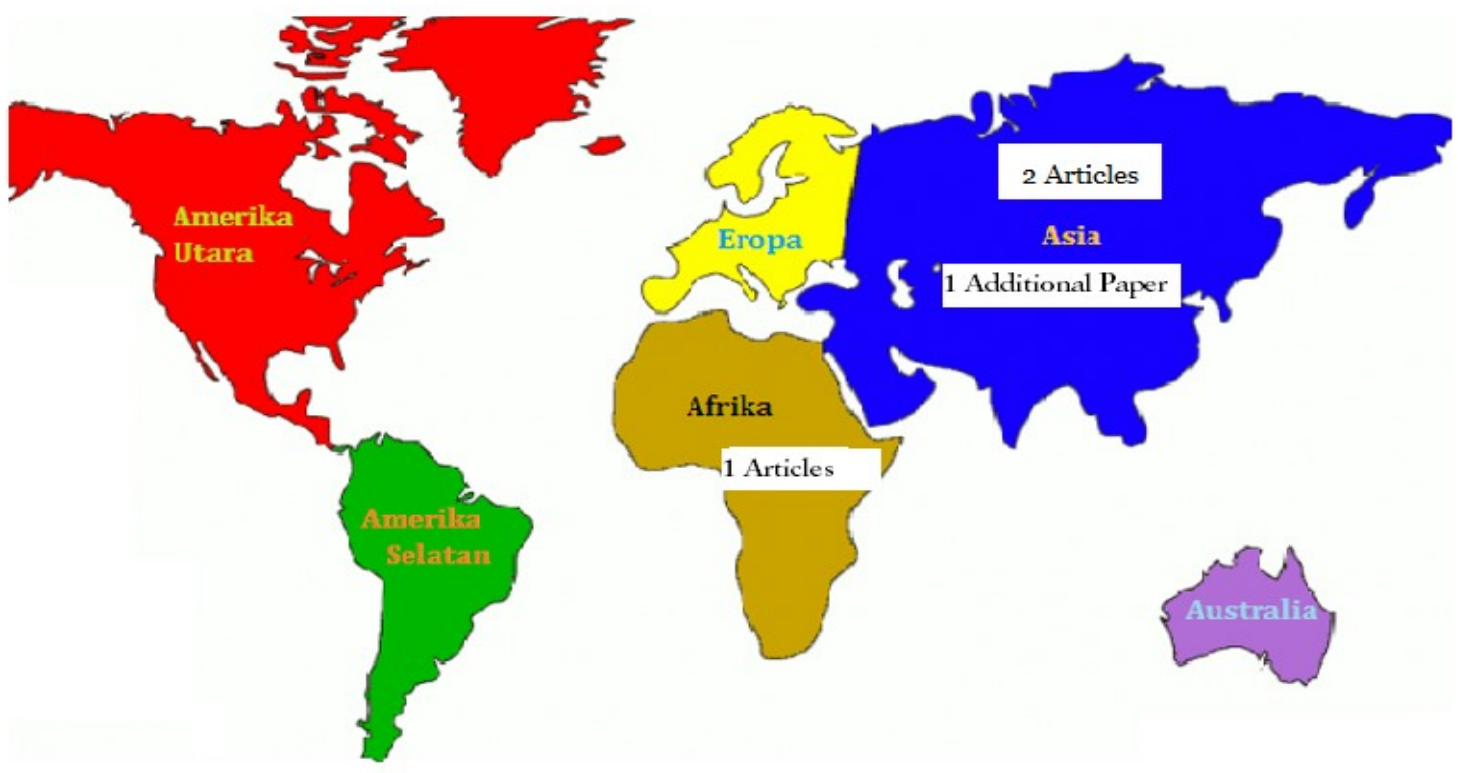

Figure 2. Map of the study area 
JKPH

\section{Overweight}

Table 1 showed primary study sources of meta-analysis of the relationship of overweight with hypertension. Table 1 showed that there
Journal of Epidemiology and Public Health (2020), 05(01): 88-96 Masters Program in Public Health, Universitas Sebelas Maret
Meta-

Analysis

Table 1. Primary study sources of meta-analysis of the relationship of overweight with hypertension

\begin{tabular}{llcc}
\hline Author (year) & Country & aOR & 95\% CI \\
\hline Farahat and Saleem (2007) & Arab Saudi & 1.39 & $0.84-2.30$ \\
Ganesh et al. (2014) & India & 1.22 & $0.39-3.82$ \\
Tefasye (2017) & Ethiopia & 1.50 & $0.90-2.50$
\end{tabular}

a. Forest plot

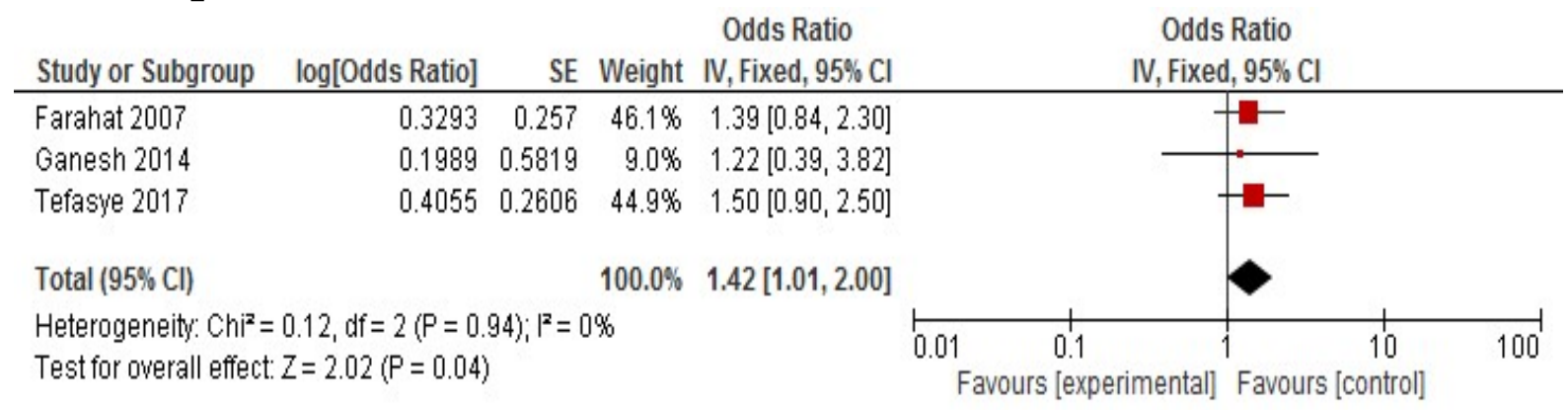

Figure 3. Forest plot relationship overweight as a risk factor for hypertension in the police and military

Figure 3 shows the results of the forest plot that police and military who are overweight can increase the risk of hypertension by 1.42 times compared to police and military who are not overweight. were 2 articles of cross sectional study and 1 articles case control study of overweight and hypertension in the police and military.

\section{b. Funnel plot}

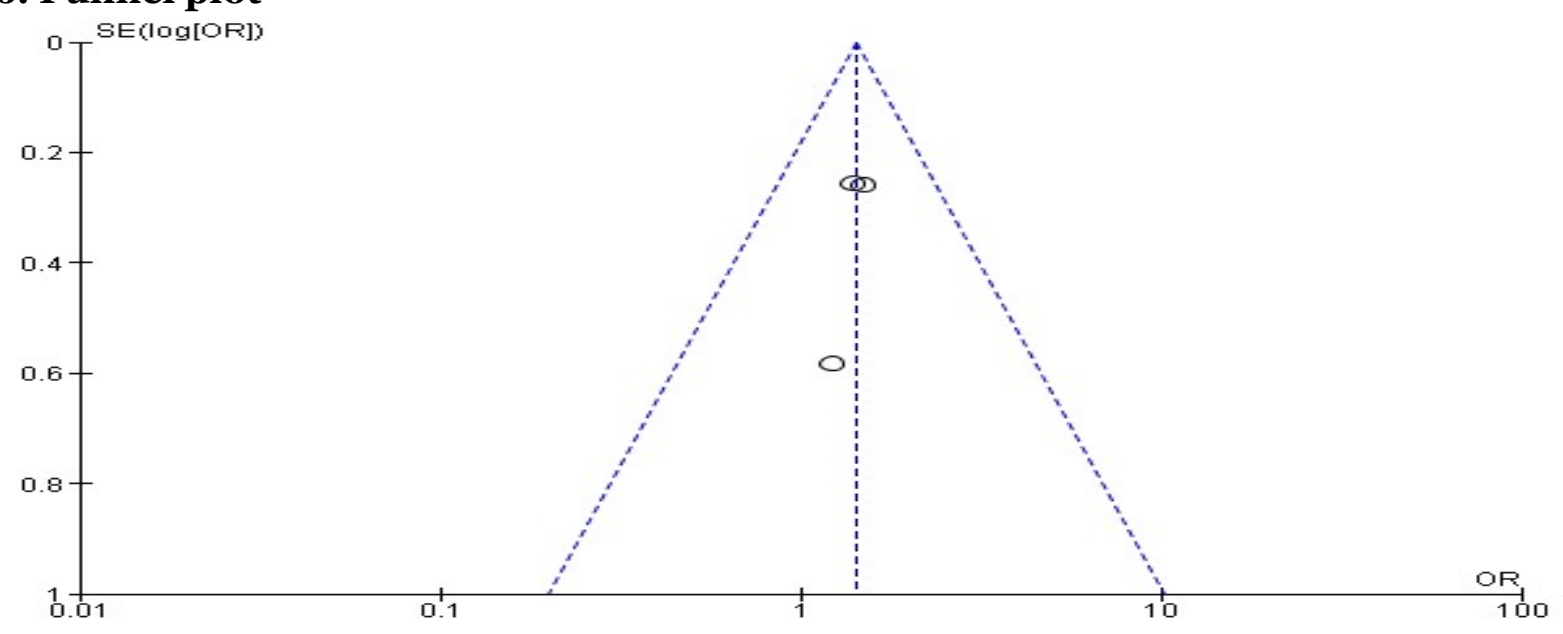

Figure 4. Funnel plot influences of being overweigh as a risk factor for hypertension in the police and military 
Figure 4 shows that there is no publication bias which is indicated by the symmetric axis which is shown as a balanced sideleft plot and right plot. The left plot has a standard error of 0.6 to 0.2 and the plot on the right has a 0.2 .

\section{Alcohol Consumption}

Table 2 shows that there are 3 articles of cross sectional study on alcohol consumption which are risk factors for hypertension in the police and military.

Table 2. Primary study sources of meta-analysis of alcohol consumption with hypertension

\begin{tabular}{llcc}
\hline Author (year) & Country & aOR & 95\% CI \\
\hline Ganesh (2014) & India & 1.79 & $1.00-3.20$ \\
Tefasye (2017) & Ethiopia & 1.20 & $0.65-2.20$ \\
Rastogi (2003) & India & 1.64 & $1.01-2.66$ \\
\hline
\end{tabular}

a. Forest plot

\begin{tabular}{|c|c|c|c|c|c|c|c|}
\hline Study or Subgroup & log[Odds Ratio] & SE & Weight & $\begin{array}{l}\text { Odds Ratio } \\
\text { IV, Fixed, } 95 \% \mathrm{Cl}\end{array}$ & $\begin{array}{l}\text { Odds } \\
\text { IV, Fixed }\end{array}$ & Ratio & \\
\hline Ganesh 2014 & 0.5822 & 0.2971 & $29.7 \%$ & $1.79[1.00,3.20]$ & & $\square-$ & \\
\hline Rastogi 2003 & 0.4947 & 0.2473 & $42.9 \%$ & $1.64[1.01,2.66]$ & & - & \\
\hline Tefasye 2017 & 0.1823 & 0.3093 & $27.4 \%$ & $1.20[0.65,2.20]$ & & $=-$ & \\
\hline Total $(95 \% \mathrm{Cl})$ & & & $100.0 \%$ & $1.55[1.12,2.12]$ & & & \\
\hline \multicolumn{4}{|c|}{$\begin{array}{l}\text { Heterogeneity: } \mathrm{Chi}^{2}=0.97, \mathrm{df}=2(\mathrm{P}=0.62) ; \mathrm{I}^{2}=0 \% \\
\text { Test for overall effect: } Z=2.69(\mathrm{P}=0.007)\end{array}$} & & \begin{tabular}{|lc}
0.01 & 0.1 \\
& Favours [experimental]
\end{tabular} & $\begin{array}{cc}10 \\
\text { Favours [control] }\end{array}$ & 100 \\
\hline
\end{tabular}

Figure 5. Forest plot alcohol consumption as a risk factor for hypertension in the police and military

Figure 5 shows the results of the forest plot shows that police and military who consume alcohol can increase hypertension by 1.55 times compared to police or military who do not consume alcohol. The result was statistically significant $(\mathrm{p}=0.007)$. Heterogenity of $\mathrm{I}^{2}=0 \%$ indicates homogeneous data spread (fixed effect model).

\section{b. Funnel plot}

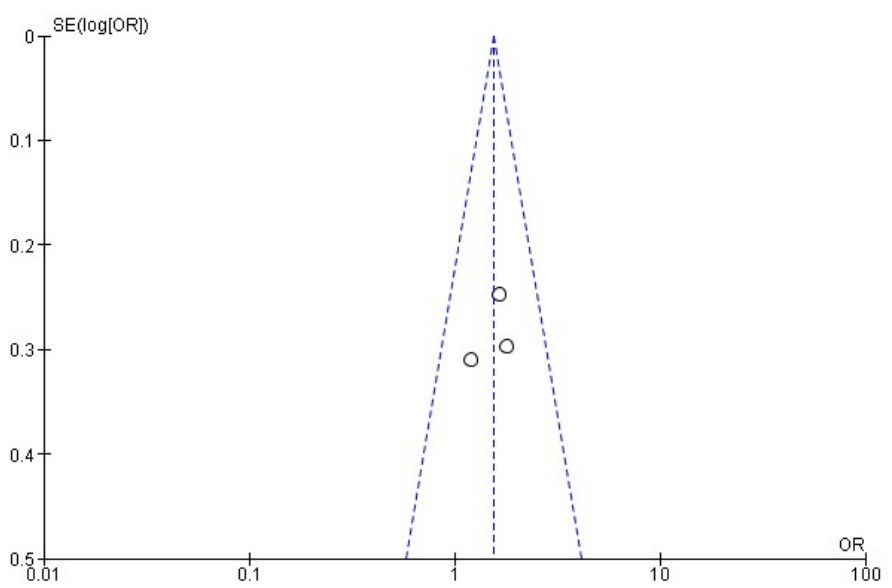

Figure 6. Funnel plot of alcohol consumption as a risk factor for hypertension in the police and military 
Figure 6 shows that there is no publication bias which is indicated by the symmetry axis which is shown as a balanced sideleft plot and right plot. The left plot has a standard error of 0.3 to 0.2 and the plot on the right has a standard error between 0.3 to 0.2 .

\section{Smoking Consumption}

Table 3 shows that there are 1 cross sectional study and 1 case control study articles on cigarette consumption which are risk factors for hypertension in the police and military.

Table 3. Primary study sources of meta-analysis of smoking with hypertension

\begin{tabular}{llcc}
\hline Author (year) & Country & aOR & 95\% CI \\
\hline Farahat and Saleem (2007) & Arab Saudi & 1.45 & $1.06-1.97$ \\
Tefasye (2017) & Ethiopia & 1.40 & $0.50-3.92$ \\
\hline
\end{tabular}

a. Forest Plot

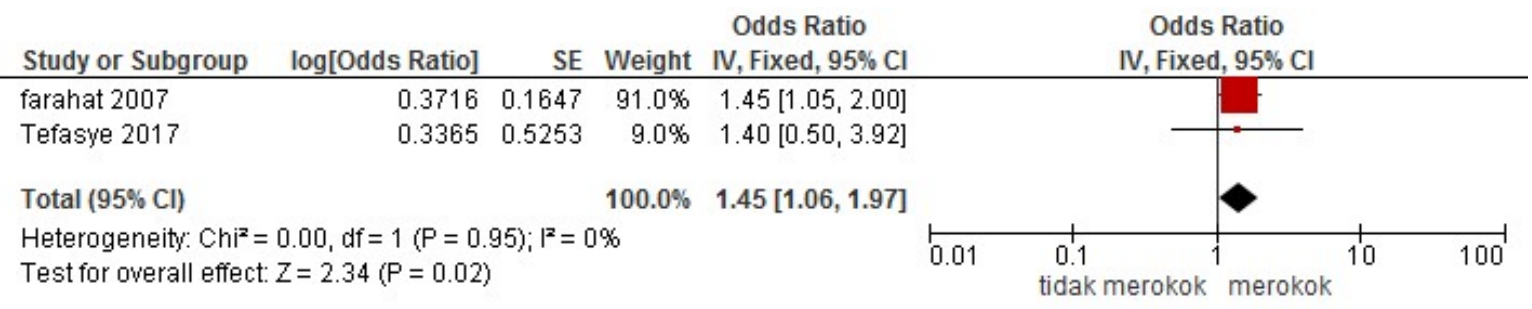

Figure 7. Forest plot cigarette smoke as a risk factor for hypertension in the police and military

Figure 7 showed that cigarette consumption can increase the incidence of hypertension in the police and military by 1.45 times com- pared to non-cigarette consumption, and is statistically significant $(\mathrm{p}=0.020)$.

\section{b. Funnel plot}

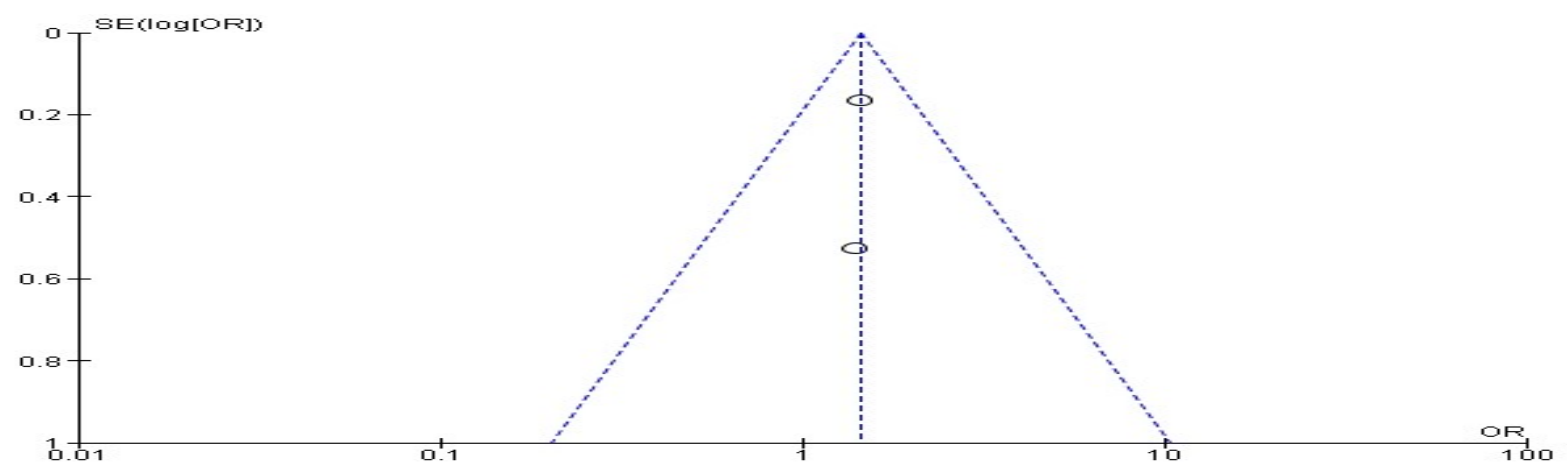

Figure 8. Funnel plot of cigarette consumption as a risk factor for hypertension in the police and military

Figure 8 shows the absence of publication bias marked by the symmetrical plot on the left and right sides that are at a vulnerable 0.6 to 0.2 .

\section{DISCUSSION}

1. Overweight with hypertension

The results of a meta-analysis of five articles on overweight and hypertension in the police 
and military show that being overweight is a risk factor for hypertension and can increase the risk 1.42 times compared to normal weight.

The results of this study are supported by research by Mallik et al. (2014) who reported that being overweight can increase 1.37 times the risk of hypertension compared to normal weight. Research Saad et al. (2017) which shows that being overweight (overweight) has a significant relationship with hypertension.

The mechanism of the influence of overweight on blood pressure is closely related to fat deposits in the body. People who are overweight, their hearts work harder to pump blood. This is because the blood vessels of fat people pinched on fatty skin. Overweight people cause their body to work hard to burn excess calories. Burning these calories requires an adequate supply of oxygen. The more calories you burn, the more oxygen you have in your blood. The amount of blood supply causes the heart to work harder so that blood pressure tends to be higher (Widharto, 2007).

\section{Alcohol consumption with hyper- tension}

The results of a meta-analysis of three articles on alcohol consumption and hypertension in the police and military showed that alcohol consumption is a risk factor for hypertension and can increase the risk 1.55 times compared to not consuming alcohol.

Increased blood pressure due to alcohol consumption is unclear. However, it is thought that an increase in cortisol levels and an increase in the volume of red blood cells and blood viscosity play a role in raising blood pressure. Several studies show a direct relationship between blood pressure and alcohol intake and among others report that effects on blood pressure are only seen when consuming alcohol around 2-3 glasses of standard size every day (Ministry of Health, 20-
13). An increase in alcohol consumption in the long run will affect the increase in cortisol levels in the blood so that the activity of the reninangiotensin aldosterone system (RAAS) will increase ie the hormone system that regulates blood pressure and fluid balance in the body. In addition, if a person consumes alcohol the volume of red blood cells in his body will increase. This will increase blood viscosity which can increase blood pressure (Elvivin et al., 2016).

\section{Consumption of cigarettes with hy- pertension}

The results of a meta-analysis of two articles on cigarette consumption and hypertension in the police and military showed that cigarette consumption is a risk factor for hypertension and can increase the risk 1.45 times compared to not consuming cigarettes. The results of this study are supported by Oktavia and Martini (2016) who report that cigarette consumption can increase 2.61 times the risk of hypertension compared to not consuming cigarettes. Saad et al. (2017) reported that cigarette consumption has a significant relationship with hypertension.

Toxic chemicals such as nicotine and carbon monoxide that are inhaled through cigarettes will enter the blood circulation and damage the endothelial lining of arteries, which results in the process of artereosclerosis and high blood pressure. In the autopsy study, it was proven that there was a close relationship between smoking and the process of atherosclerosis in all blood vessels. Smoking also increases heart rate, so the oxygen demand of the heart muscle increases. Smoking in people with high blood pressure will further increase the risk of damage to blood vessels (Ministry of Health, 2013).

Chemicals in cigarettes can damage the lining of the arterial walls in the form of plaque which causes narrowing of blood vessels which can increase blood pressure. Nicotine increases the hormone epinephrine which 
can increase blood vessel constriction (Aghi and Herbert, 2012).

\section{AUTHOR CONTRIBUTION}

Firman Pardosi is the main author who selects topics, and collects data; Setyo Sri Rahardjo gave suggestion and corrected the manuscript; Yulia Lanti Retno Dewi did data analysis.

\section{CONFLICT OF INTEREST}

There is no conflict of interest in this study.

\section{FUNDING AND SPONSORSHIP}

This study is self-funded.

\section{ACKNOWLEDGEMENT}

We would like to show our gratitude to electronic database providers Google Scholar, Springer Link, Science Direct and ProQuest.

\section{REFERENCE}

Aghi C, Herbert B (2012). Menurunkan tekanan darah (Reducing blood pressure). Jakarta: PT. Buana Ilmu Populer Kelompok Gramedia.

Elvivin E, Lestari H, Ibrahim K (2016). Analisis faktor risiko kebiasaan mengkonsumsi garam, alkohol, kebiasaan merokok dan minum kopi terhadap kejadian hipertensi pada nelayan Suku Bajo Di PulauTasipi Kabupaten Muna Barat Tahun 2015 (Risk factor analysis of salt, alcohol, habitual habits of smoking and drinking coffee against the occurrence of hypertension in Bajo Fishermen on Tasipi Island, West Muna Regency 2015). Jurnal Ilmiah Mahasiswa Kesehatan Masyarakat, 1(3): 1-12. Retrieved from: http://ojs.uho.ac.id/index.php/JIMKESMAS/article/view/1273/920

Farahat FM, Saleem FA (2007). Communitybased screening for pre-hypertension among military active duty personnel. Bull High Inst Public Health, 37(1): 112123. https://doi.org/10.21608/jhiph.2-
007.22018

Ganesh KS, Naresh AGV, Bammigatti C (2014). Prevalence and risk factors of hypertension among male police personnel in urbanPuducherry, India. Kathmandu Univ Med. 12(48):242-246. https://10.3126/kumj.v12i4.13728

Ministry of Health (2013). Pedoman teknis penemuan dan tatalaksana hipertensi (Technical guidelines for the discovery and management of hypertension). Retrieved from: http://www.p2ptm.kemkes.go.id/site/dokumen-ptm/pedoman-teknis-penemuan-dan-tatalaksana-hipertensi/

Ministry of Health (2014). Infodatin Hipertensi. Jakarta. Retrieved from: https://www.kemkes.go.id/resources/downloa d/pusdatin/infodatin/infodatin-hipertensi.pdf

Mallik D, Mukhopadhyay DK, Kumar P, Sinhababu A (2014). Hypertension, Prehypertension and normotension among police personnel in a district of West Bengal, India. J Assoc Physicians India, 62(11): 12-16. Retrieved from: https://pdfs.semanticscholar.org/dc78/8d4bc18ee83da8699eoc22fa7fo3a3389366.pdf?_ga=2.71774547.1556029609.1584706983-1919778915.1578765265

Oktavia F, Martini S (2016). Besar risiko kejadian hipertensi berdasarkan faktor perilaku pada Tentara Nasional Indonesia (TNI) (High risk of occurrence of hypertension based on behavioral factors in the Indonesian National Army (TNI)). Media Kesehatan Masyarakat Indonesia, 12(3): 127-136. https:// doi.org/10. 30597/MKMI.V12I3.1067

Rastogi P (2003). Diet and High Blood Pressure. South Asian Journal of Preventive Cardiology. http://www.sajpc.org/voly/vol9_2/highprevalenceofcoronaryhear tdisease.htm 


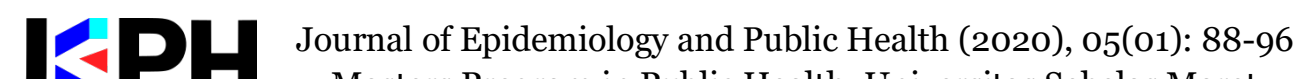
Masters Program in Public Health, Universitas Sebelas Maret

Meta-

Analysis

Saad A, Shehri A, Afifi R, Tashkandi M (2017). Prevalence and correlates of prehypertension and hypertension resultsII: A screening plan in a selected military community in central Saudi Arabia. Car diol Angiol, 6(2): 121. https://doi.org/10.9734/ca/2017/32180.

Saputra O, Anam K (2016). Gaya hidup sebagaifaktor risiko hipertensi pada masyarakat pesisir pantai (Lifestyle as a risk factor for hypertension in Coastal Communities). Majority, 5(3): 118-123. Retrieved from: https://juke.kedokteran.unila.ac.id/index.php/majority/article/view/1047/842
Tesfaye T (2017). Assessment of the prevalence of hypertension and associated factors among Ethiopian Federal Police Officers Addis Ababa, Ethiopia: A Community Based Cross-Sectional Study. Ec Cardiology, 26: 278-286. Retrieved from: https://www.ecronicon.com/eccy/pdf/ECCY-02-0004 0. pdf

WHO (2019). Hypertension. Retrieved from: https://www.who.int/newsroom/factsheets/detail/hypertension.

Widharto (2007). Bahaya hipertensi. Jakarta: Sunda Kelapa Nusantara. 